ISSN 0258-7122

Bangladesh J. Agril. Res. 36(2) : 263-270, June 2011

\title{
GENETIC VARIABILITY OF SOME CYTOPLASMIC MALE STERILE LINES (CMS) OF RICE (Oryza sativa L.) GENOTYPES
}

\author{
M. J. HASAN ${ }^{1}$, UMMA KULSUM ${ }^{2}$, M. H. RAHMAN ${ }^{3}$ \\ M. HAZRAT ALI ${ }^{4}$ AND A. W. JULFIQUAR ${ }^{5}$
}

\begin{abstract}
The desirable characteristics of fourteen genetically diverse CMS lines were assessed for their phenotypic acceptability, plant height $(\mathrm{cm})$, days to 50\% flowering. panicles per plant, stability for pollen sterility, panicle exertion rate and out crossing rate. The CMS lines viz. BRRI1A. IR 58025A. BRRI10A. BRRI9A. BRRI3A, IR 75608A, and 1132A have been found to be usable female parents for hybrid rice breeding due to their appreciable phenotypic acceptability, stable pollen sterility, panicle exertion rate and good out crossing rate. Panicle exertion rate of CMS lines had moderate heritability $(38.34 \%)$ coupled with low genetic advance $(2.34 \%)$ expected in the subsequent generations, that proved to be vulnerable to environmental fluctuation. The genotypic and phenotypic coefficient of variation was not remarkably varied from each other for most of the characters studied, indicated negligible environmental influence on these traits. Overall genetic correlation coefficients were higher than corresponding phenotypic correlation coefficients indicated strong relation present among the studied characters.
\end{abstract}

Keywords: Genetic variability, CMS lines, rice.

\section{Introduction}

Bangladesh is the fourth largest producer and consumer of rice in the world with an annual production ranging from 21 to 22 million tons (Bhuiyan et al., 2002). Rice occupies $77 \%$ of total cropped area. At present, rice alone constitutes about $92 \%$ of the total food grain produced annually in the country. It provides $75 \%$ of the calories and $55 \%$ of the proteins in the average daily diet of the people (Bhuiyan et al., 2002). A modest estimate suggests that the demand for rice in Bangladesh will increase by over $80 \%$ in the next 20 years to feed the growing population (Zaman, 1996). It is growing concern among the scientists and planners about how to feed the extra millions in future when the productivity of modern rice varieties (MVs) is stagnated and the land and water resources are shrinking. To produce the required quantity, the only option remains open is to increase production per unit area, as there is scarcity of land.

${ }^{1}$ Senior Scientific Officer, ${ }^{2 \& 3}$ Scientific Officer, ${ }^{4}$ Principal Scientific Officer, ${ }^{5}$ Project Director, Hybrid Rice Project, Bangladesh Rice Research Institute (BRRI), Gazipur 1701, Bangladesh. 
Use of rice hybrids is getting popular in Bangladesh day by day. It started in 1998 with few tons and in the year 2008 the quantity rose to 11000 tons of which 2800 tons arc locally produced. (Anwer Faruque, 2009). Shifting the yield frontier in rice, one of the best options available to plant breeders is hybrid rice. The discovery of CMS in rice suggested that breeding could develop a commercially viable $F_{1}$ hybrid (Athwal and Virmani, 1972). The most promising hybrids yielded 20-30\% (Lin and Yuan, 1980) and 15-20\% (Yuan, 1998) higher than the best conventional rice varieties, respectively. According to Siddiq (1993), a substantial increase in yield (20-30\%) is possible through selective improvement of major yield components. Therefore, to break through the present yield ceiling of semi dwarf modern varieties, hybrid rice seems to be an attractive viable alternative. It is urgently needed to develop parental lines viz. A lines, B lines and $\mathrm{R}$ lines for developing hybrid rice arieties. Presently Bangladesh is depended on imported hybrid mostly Chinese Origin and most of the imported hybrid belong to the same cytoplasmic source. If somehow this cyto source is affected by disease or any environmental changes it will cause severe damage or even epidemic. This situation could be reduced by developing CMS lines having diverse cytoplasmic source with stable male sterility, high out crossing rate, good resistance to diseases and other stresses. Similarly corresponding maintainer lines should have the ability to maintain CMS lines properly. Qn the other hand, restorer line should have high pollen load, taller than CMS lines, high adaptability and as per growth duration of CMS lines. Therefore, the present studies were undertaken to study the variability of some CMS lines for different characters to access their pollen sterility status and other desirable characters for using in hybrid rice breeding program.

\section{Materials and Method}

The experiment was conducted at the experimental field of Bangladesh Rice Research Institute (BRRI), Gazipur during Boro season 2007-2008. Fourteen genotypes of different origin were used in the study (Table 1). The experiment was laid out in completely randomized design with three replications. Thirty days old seedlings were transplanted in a single row of 15 plants using single seedlings per hill with the spacing of $20 \mathrm{~cm}$ x $20 \mathrm{~cm}$. Fertilizer application and other cultural management practices were performed as per recommendation of Boro season. Days to first flowering, days to $50 \%$ flowering, plant height, effective tillers per plant, panicles per plant, panicle length, panicle exertion rate, out crossing rate, and pollen sterility status of the CMS lines were determined by staining pollen grains in 1.5\% Potassium Iodide Iodine (IKI) solution. Based on iodine and starch interaction pollen grains were classified into typical abortive, round sterile and partial stained types and microscope count was taken and expressed in terms of percentage. Two to three plants were bagged at heading stage and mean sterility was recorded properly. 
Table 1. List of the CMS lines with different cyto source and origin.

\begin{tabular}{llll}
\hline SL. No. & Designation & Cyto source & Origin \\
\hline 01 & BRRI IA & WA & Bangladesh \\
02 & BRRI 3A & WA & Bangladesh \\
03 & BRRI 9A & Gambiaca & Bangladesh \\
04 & BRRII0A & WA & Bangladesh \\
05 & 1132 A & WA & China \\
06 & IR 68888 A & WA & Philippines \\
07 & IR 58025 A & WA & Philippines \\
08 & Jin23 A & WA & China \\
09 & IR 73328 A & Mutagenized IR 62829A & Philippines \\
10 & IR 78362 A & Dissi & Philippines \\
11 & IR 78355 A & Gambiaca & Philippines \\
12 & IR 62829 A & WA & Philippines \\
13 & IR 75608 A & Kalinga & Philippines \\
14 & IR 68897 A & WA & Philippines \\
\hline
\end{tabular}

\section{Results and Discussion}

Results revealed that out crossing rate varied significantly among the CMS lines (Table 2) suggested out crossing rate appeared as less flexible over the genetic background of the CMS lines. Days to $50 \%$ flowering, panicles per plant and panicle exertion rate (\%) were expressed differentially in different CMS lines. Duration of CMS lines ranged from I 18 to 141 days. CMS line IR 78362A had the shortest growth duration and BRRI 9A had the highest duration. Most of the tested CMS lines were found stable in respect of pollen sterility (Table 2). Days to first flowering ranged from 87 to 105 days. The CMS line BRRI 9A required the longest time for days to first flowering that was significantly different from rest of the CMS lines. Similarly the CMS line BRRI 9A took the highest duration to attain days to $50 \%$ flowering. The CMS line BRRI 10A showed the highest plant height as compared to others, but it was statistically closer to the CMS lines, IR 78355A, BRRI 9A, and IR 75608A. The other CMS lines exhibited medium short stature. The maximum number of effective tillers per plant was recorded in the CMS line IR 62829A. Panicle length ranged from 19.71 to 25.01 $\mathrm{cm}$. The longest panicle length was found in CMS line IR 78355A and it was identical to the CMS line IR 75608A and BRRI IA. The panicle exertion rate ranged from 74.80 to $81.57 \%$ among the CMS lines. The highest was recorded in CMS line 1R78355A and the lowest was in BRRI 3A. Out crossing rate ranged from 1.91 to $13.73 \%$. 


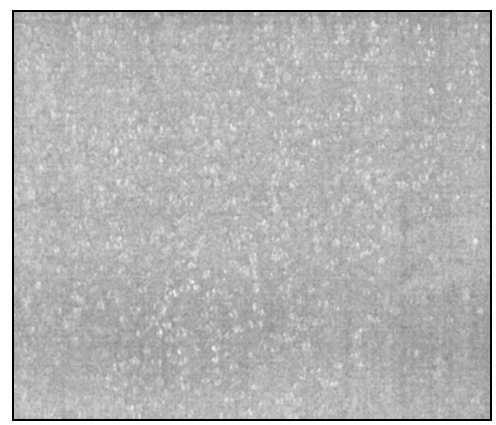

Fig. Microscopic view of CMS line BRRI 9A

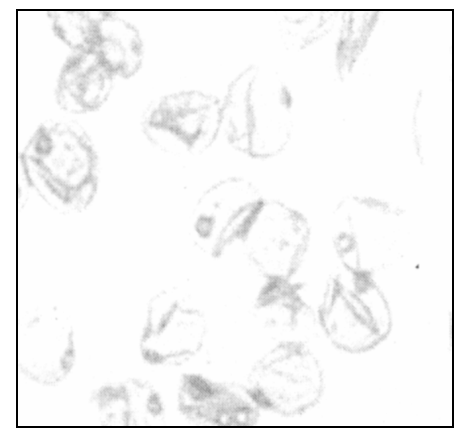

Fig. Microscopic view of CMS line BRRI 10A

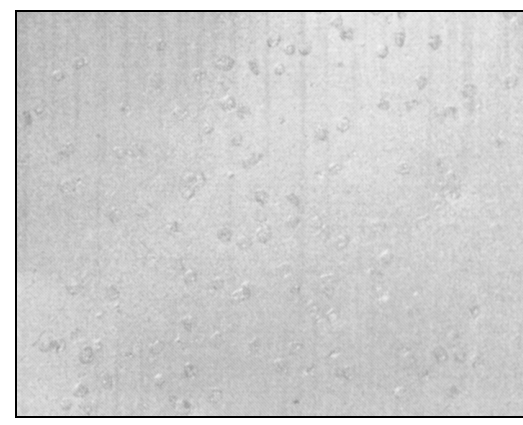

Fig. Microscopic view of CMS line $1132 \mathrm{~A}$

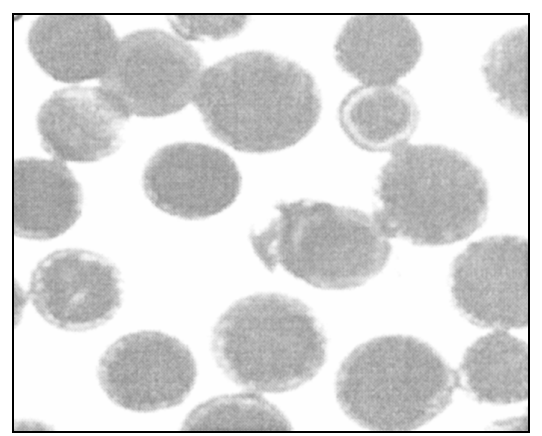

Fig. Microscopic view of Maintainer line BRRI 10B

The maximum coefficient of variation $24.09 \%$ indicated that out crossing rate was remarkably varied in the trial that could be minimized by statistical inference. Laut et al. (1994) reported significant difference in out crossing potential among the CMS lines. The genotypic and phenotypic coefficient of variations, broad sense heritability, and genetic advance in percent of mean are presented in Table 3. Genetic coefficient of variation (GCV) ranged from 1.853 to 47.498 and phenotypic coefficient of variation (PCV) from 2.963 to 53.258. The genotypic and phenotypic coefficient of variations did not remarkably differ in the tested entry for most of the characters studied, indicating minimum environmental influence on these traits. Days to first flowering and days to $50 \%$ flowering showed high magnitudes of heritability and medium genetic advances hut low variations among the CMS lines. Chakraborty and Hajarika (1994) reported low variation and high heritability with moderate genetic advance for days to flowering. Maury and Singh (1986) reported that high heritability along with high genetic advance could be the effect for high selection response in low land rice. Plant height exhibited high heritability and moderate genetic advance but the difference between GCV and PCV was 
Table 2. Performance of different characters of 14 cytoplasmic male sterile (A) lines.

\begin{tabular}{|c|c|c|c|c|c|c|c|c|c|}
\hline Genotypes & $\begin{array}{l}\text { Plant } \\
\text { height } \\
(\mathrm{cm})\end{array}$ & $\begin{array}{l}\text { Effective } \\
\text { tillers/plant }\end{array}$ & $\begin{array}{l}\text { Days to first } \\
\text { flowering }\end{array}$ & $\begin{array}{c}\text { Days to } 50 \% \\
\text { flowering }\end{array}$ & $\begin{array}{c}\text { Panicle } \\
\text { length }(\mathrm{cm})\end{array}$ & $\begin{array}{l}\text { Days to } \\
\text { maturity }\end{array}$ & PER (\%) & OCR $(\%)$ & $\begin{array}{c}\text { Sterility } \\
\text { status (\%) }\end{array}$ \\
\hline BRRI I A & $60.28 \mathrm{E}$ & $11.93 \mathrm{AB}$ & $95.0 \mathrm{CC}$ & $101.3 \mathrm{C}$ & $24.21 \mathrm{ABC}$ & $130 \mathrm{C}$ & $81.30 \mathrm{AB}$ & $13.73 \mathrm{~A}$ & $000.0 \mathrm{CD}$ \\
\hline BRRI 3A & 63.70CD & $12.02 \mathrm{AB}$ & 93.67CD & $100.0 \mathrm{CD}$ & $20.40 \mathrm{EF}$ & $130 \mathrm{C}$ & $74.80 \mathrm{D}$ & $8.62 \mathrm{CD}$ & $100.0 \mathrm{~A}$ \\
\hline BRRI 9A & 71.29AB & $10.58 \mathrm{ABC}$ & $105.30 \mathrm{~A}$ & $112.0 \mathrm{~A}$ & 23.32BCD & $141 \mathrm{~A}$ & $80.02 \mathrm{ABC}$ & $9.24 \mathrm{BC}$ & $100.0 \mathrm{~A}$ \\
\hline BRRI 10A & $76.66 \mathrm{~A}$ & $10.63 \mathrm{ABCD}$ & $94.00 \mathrm{CD}$ & 97.67D & $19.71 \mathrm{~F}$ & $129 \mathrm{C}$ & $80.15 \mathrm{ABC}$ & $12.33 \mathrm{AB}$ & $100.0 \mathrm{~A}$ \\
\hline II $32 \mathrm{~A}$ & $60.59 \mathrm{DE}$ & 10.84ABCD & $88.67 \mathrm{GH}$ & $91.67 \mathrm{FG}$ & $20.89 \mathrm{EF}$ & $122 \mathrm{~F}$ & 78.00ABCD & $7.12 \mathrm{CD}$ & $99.0 \mathrm{AB}$ \\
\hline IR68888A & $60.46 \mathrm{DE}$ & 10.20BCD & 89.67EFGH & 93.67EFG & 21.89DE & $125 \mathrm{E}$ & $77.46 \mathrm{CD}$ & 6.04CDEF & $100.0 \mathrm{~A}$ \\
\hline IR58025A & $58.78 \mathrm{DE}$ & 10.06BCD & 91.33DEFG & $94.33 \mathrm{EF}$ & 21.91DE & $127 \mathrm{D}$ & 78.79ABC & $12.73 \mathrm{AB}$ & $99.0 \mathrm{AB}$ \\
\hline Jin $23 \mathrm{~A}$ & $59.78 \mathrm{DE}$ & $8.863 \mathrm{CD}$ & $87.00 \mathrm{H}$ & $91.33 \mathrm{G}$ & $20.09 \mathrm{~F}$ & $121 \mathrm{~F}$ & 79.97ABC & 6.78CDE & $100.0 \mathrm{~A}$ \\
\hline IR73328A & $62.63 \mathrm{D}$ & 11.36ABC & 92.33CDE & $95.00 \mathrm{E}$ & $22.98 \mathrm{CD}$ & $126 \mathrm{E}$ & 79.52ABC & $4.59 \mathrm{DEF}$ & $100.0 \mathrm{~A}$ \\
\hline IR78362A & $63.54 \mathrm{CD}$ & 10.23BCD & $89.00 \mathrm{FGH}$ & $92.33 \mathrm{EFG}$ & $22.55 \mathrm{D}$ & $118 \mathrm{G}$ & 77.09CD & $1.91 \mathrm{~F}$ & $100.0 \mathrm{~A}$ \\
\hline IR78355A & $74.65 \mathrm{~A}$ & 10.91ABCD & 99.33B & 105.0B & $25.01 \mathrm{~A}$ & 134B & $81.57 \mathrm{~A}$ & $2.44 \mathrm{EF}$ & $100.0 \mathrm{~A}$ \\
\hline IR62829A & $62.35 \mathrm{D}$ & $13.37 \mathrm{~A}$ & 92.00CDEF & $99.00 \mathrm{CD}$ & $21.88 \mathrm{DE}$ & $130 \mathrm{C}$ & 78.37ABC & $6.04 \mathrm{DEF}$ & $98.0 \mathrm{AB}$ \\
\hline IR75608A & $71.24 \mathrm{AB}$ & $8.050 \mathrm{D}$ & $94.00 \mathrm{CD}$ & $100.0 \mathrm{CD}$ & $24.78 \mathrm{AB}$ & $128 \mathrm{CD}$ & $78.55 \mathrm{ABC}$ & 7.79CD & $100.0 \mathrm{~A}$ \\
\hline IR68897A & $68.50 \mathrm{BC}$ & $10.46 \mathrm{CD}$ & $93.33 \mathrm{CD}$ & 99.67CD & 23.32BCD & $129 \mathrm{C}$ & 77.78CD & 4.21DEF & $100.0 \mathrm{~A}$ \\
\hline $\mathrm{CV}(\%)$ & 3.57 & 10.3 & 1.33 & 1.18 & 2.87 & 4.43 & 2.33 & 24.09 & 0.61 \\
\hline S.E $( \pm)$ & 1.340 & 0.638 & 0.715 & 0.669 & 0.371 & 1.51 & 1.059 & 1.030 & 0.163 \\
\hline
\end{tabular}

$\mathrm{PER}=$ Panicle exertion rate, $\mathrm{OCR}=$ Out crossing rate. 
minimum. Kihupi and Doto (1989) reported similar results on this trait. Panicle exertion rate estimation resulted medium heritability and low genetic advance suggesting that the trait was controlled by non additive genes and vulnerable to environmental fluctuation. Out crossing rate had appreciable heritability and genetic advance expected in the next generation. In general, genotypic correlation coefficients were higher than corresponding phenotypic correlation coefficients, suggesting strong inherent relation among the characters. However, among the 21 associations, 3 pair of combinations first flowering with 50\% flowering, 50\% flowering with plant height and plant height with panicle length showed significance both at genotypic and phenotypic levels (Table 4).

Table 3. Genetic parameters for different characters of 14 tested centries.

\begin{tabular}{ll|l|l|l|c|c}
\hline \multicolumn{1}{c}{ Characters } & \multicolumn{1}{c|}{ Range } & Mean & GCV & PCV & $\mathrm{h}^{2} \mathrm{~b}$ & $\mathrm{GA}(\%)$ \\
\hline $\begin{array}{l}\text { Dys to first flowering } \\
\text { (A line) }\end{array}$ & $87-105$ & 93.19 & 4.96 & 5.135 & 93.305 & 9.869 \\
$\begin{array}{l}\text { Days to 50\% flowering } \\
\text { (A line) }\end{array}$ & $91-112$ & 98.071 & 5.796 & 5.915 & 96.012 & 11.699 \\
Plant height (cm) & $56-77$ & 65.045 & 9.467 & 10.116 & 87.566 & 18.248 \\
Panicles per plant & $8-13$ & 10.679 & 10.689 & 14.877 & 51.624 & 15.824 \\
Panicle length (cm) & $19.71-25.01$ & 22.353 & 7.413 & 7.951 & 86.926 & 14.235 \\
\hline PER (\%) & $74.80-81.57$ & 78.812 & 1.835 & 2.963 & 38.339 & 2.34 \\
OCR (\%) & $1.91-13.73$ & 7.405 & 47.498 & 53.258 & 79.541 & 87.271 \\
\hline
\end{tabular}

$\mathrm{PER}=$ Panicle exertion rate, $\mathrm{OCR}=$ Out crossing rate

Table 4. Genotypic and phenotypic correlation coefficients between yield and yield components in $14 \mathrm{CMS}$ lines of rice.

\begin{tabular}{ll|c|c|c|c|c|c}
\hline \multicolumn{1}{c}{ Parameters } & & $\begin{array}{c}50 \% \\
\text { flowering } \\
\text { (A line) }\end{array}$ & $\begin{array}{c}\text { Plant } \\
\text { height } \\
(\mathrm{cm})\end{array}$ & $\begin{array}{c}\text { Panicles/ } \\
\text { plant }\end{array}$ & PER (\%) & $\begin{array}{c}\text { Panicle } \\
\text { length } \\
(\mathrm{cm})\end{array}$ & OCR (\%) \\
\hline First flowering & $\mathrm{G}$ & $0.979^{* *}$ & $0.666^{*}$ & 0.155 & 0.491 & 0.525 & -0.459 \\
(A line) & $\mathrm{P}$ & $0.962^{* *}$ & 0.588 & 0.155 & 0.271 & 0.487 & 0.406 \\
$50 \%$ flowering & $\mathrm{G}$ & & $0.725^{* *}$ & 0.237 & 0.536 & 0.501 & -0.374 \\
(A line) & $\mathrm{P}$ & & $0.663^{*}$ & 0.170 & 0.517 & 0.471 & -0.331 \\
Plant height (cm) & $\mathrm{G}$ & & & 0.100 & $0.77^{* *}$ & $0.891^{* *}$ & -0.422 \\
& $\mathrm{P}$ & & -0.044 & 0.567 & $0.810^{* *}$ & -0.348 \\
Panicles per plant & $\mathrm{G}$ & & & 0.382 & -0.122 & 0.272 \\
& $\mathrm{P}$ & & & -0.022 & -0.067 & 0.295 \\
PER (\%) & $\mathrm{G}$ & & & & $0.633^{*}$ & 0.022 \\
& $\mathrm{P}$ & & & & 0.325 & -0.029 \\
Panicle length & $\mathrm{G}$ & & & & & -0.163 \\
(cm) & $\mathrm{P}$ & & & & & -0.110 \\
\hline
\end{tabular}

$\overline{\mathrm{PER}}=$ Panicle exertion rate, $\mathrm{OCR}=$ Out crossing rate, $*$ and ${ }^{* *}$ significant at $5 \%$ and $1 \%$ levels of probability, respectively. 
Days to first flowering of CMS lines were positively and significantly correlated with days to $50 \%$ flowering and plant height. The negative and nonsignificant association of CMS lines for days to first flowering with out crossing rate in hybrid rice breeding. Plant height had positive and significant association with panicle length. Dhanraj et al. (1987) found negative correlation between days to $50 \%$ flowering with plant height and tillers per plant. Panicles per plant as negatively and non-significantly associated with panicle length. Panicle exertion rate showed positive and significant association with panicle length only at genotypic level.

\section{References}

Anwer Faruque. 2009. Hybrid seed for food security. Keynote paper in the Bangladesh Seed Conference and Fair 2009 held at Bangladesh China Friendship Conference Centre during 28-30 May 2009.

AthwaI. D.S. and S.S.Virmani. 1972. Cytoplasmic male sterility and hybrid breeding in rice. Pages 615-620 in Rice Breeding. IRRI. PO Box 933. Manila. Philippines.

Bhuiyan, N.I., D.N.R. Paul and M. A. Jabbar. 2002. Feeding the extra millions by 2025: challenges for rice research and extension in Bangladesh. A key note paper presented at national workshop on rice research and extension 2002. Fleld on 29 Dec. 1 January 2002, BRRI. p. 9.

Chakraborty, S. and M. H. Hajarika. 1994. Estimation of various genetic parameters of yield and yield components of rice. Oryza 31: 226-227.

Dhanraj, A., C.A. Jagadish,and VigayUpre. 1987. Studies on character association in the $\mathrm{F}_{2}$ generation on ten selected crosses in rice (Oryza sativa L.). J. Res. APAU. 15(1): 64-65.

Karim. Z. 1998. Overview on the problems and prospects of Bangladesh Agriculture Presented at the symposium on Vision of Agricultural Research and Development held at Bangladesh Agricultural Research Council, 16 April 1998, 12 p.

Kihupi, A. N. and A. L. Doto. 1989. Genotypic and environmental variability in selected rice characters. Oryza 26(2): 129-134.

Lin, S. C. and L. P. Yuan. 1980. Hybrid rice breeding in China. In Innovative Approaches to Rice Breeding, pp. 35-51. Int. Rice Res. Inst. Manila, Philippines.

Luat. V., Nguyen, T.M. Hoang and V. S. Nguyen. 1994. Hybrid rice research in Vietnam In.: Hybrid Rice Technology: New Developments and Future Prospects. Int. Rice Res. Inst., Manila, Philippines, pp. 187-193.

Maurya, D. M., S. K. Singh and R. S. Singh. 1986. Genetic variability in 48 low land rice cultivars of Uttar Pradesh, India. Int. Rice Res. Newsletter 11(4): 13.

Siddiq, E.A. 1993. Rice Production Strategy for $21^{\text {st }}$ Century. Oryza. 30: 180-196. 
Yadav, R. K. 1992. Genetic variability and correlation studies and their implications in selection of high yielding genotypes of rice. Adv. Pl Sci. 5: 306-312.

Yuan L P. 1998. Hybrid rice breeding in China. In: Virmani SS, Siddiq EA, Muralidharan K. (editors). Advances in $\mathrm{h}$ brid rice technology. Proceedings of the $3^{\text {rd }}$ International Symposium on Hybrid Rice, 14-16 November 1996. Hyderabad, India. Manila (Philippines): International Rice Research Institute. p 27-33.

Zarnan, S. M. H. 1996. Plant Breeding Beyond. 2000 A D. A key note paper presented in the fourth Annual Conference of Plant Breeding Society of Bangladesh, BARI, Jodebpur, 24 Oct. 1996, p. 11. 